\title{
The Complementarity Between Trade In Goods And Capital Flows: An Empirical Study Of G7 Countries
}

\author{
Atul Dar, (Email: atul.dar@ smu.ca), Saint Mary’s University, Canada \\ Sal AmirKhalkhali, Saint Mary’s University, Canada
}

\begin{abstract}
This paper attempts to empirically examine whether trade in goods and assets are complementary. This is tested by assessing whether countries that are more open in terms of trade policy are also more open in terms of capital flows; that is, whether the degree of capital mobility is positively related to openness. For this purpose, we examine the dynamics of saving-investment relationship in a group of seven most industrialized countries over the 1982-2003 period using a random coefficients error correction model.
\end{abstract}

\section{INTRODUCTION}

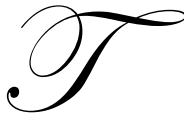

he central question that is the focus of this paper is whether countries that are more open in terms of trade policy are also more open in terms of capital flows; that is, whether the degree of capital mobility is positively related to openness. There are grounds for supposing that this might be the case. For example, the growing importance of service trade has meant that capital flows would also have grown in importance. This is because many types of service exports often require a commercial presence abroad, so that direct investment becomes a pre-requisite to trade in services. Furthermore, increased trade flows can also promote capital flows if the latter tends to be complementary to trade in goods, as noted by Feeney (1994). It is well known that when economic agents have access to international financial markets, their ability to diversify risk increases. Thus, as Feeney demonstrates with the help of a theoretical model, if trade liberalization leads to greater income uncertainty because it sharpens the degree of specialization (as predicted by a number of comparative advantage and imperfect competition models of trade), it will lead to greater trade in assets since agents have an incentive to pool away the increased risk. Indeed, the ability to diversify risk through international financial markets acts as a spur to greater specialization in production and diversification in consumption [Feeney, 1994, p.561].

The objective of this paper is to empirically determine whether trade in assets is indeed complementary to trade in goods, by examining whether greater openness to trade is associated with greater capital mobility among the most industrialized nations. This is clearly an important issue since complementarity would suggest that the gains from trade liberalization would be larger than those implied by theories of trade in goods. In assessing the impact of trade openness on capital mobility, we look at the saving-investment relationship in the seven most industrialized nations over the 1982-2003 interval. These nations consist of the so-called G-7 countries - Canada, France, Germany, Italy, Japan, the UK, and the US. The saving-investment relationship has been a common (if controversial) method of measuring the degree of capital mobility, since its pioneering use by Feldstein and Horioka (1980). The issues surrounding the use of this relationship for drawing conclusions about the degree of capital mobility have been discussed in some detail in Dar, AmirKhalkhali and AmirKhalkhali (2005) and Jansen (1996, 1998). In this paper, we model the saving-investment relationship in terms of an error-correction model with random coefficients, and use it to determine whether capital mobility and openness are related. Our data are taken from various issues of Economic Outlook published by Organization for Economic Co-operation and Development (OECD) and International Financial Statistics published by International Monetary Fund (IMF). 
The rest of the paper is organized as follows. Section II discusses the model, the estimation strategy and then presents and analyses the results. Section III concludes with a summary of the major findings and their implications.

\section{THE EMPIRICAL MODEL}

In our study, the model of the saving-investment relationship is an extension of the Jansen (1996) error correction model (ECM). Our starting point is to re-state the Jansen model as follows:

$$
\Delta(\mathrm{I} / \mathrm{Y})_{\mathrm{it}}=\alpha+\beta \Delta(\mathrm{S} / \mathrm{Y})_{\mathrm{it}}+\gamma(\mathrm{CA} / \mathrm{Y})_{\mathrm{it}-1}+\delta(\mathrm{S} / \mathrm{Y})_{\mathrm{it}-1}+\mathrm{W}_{\mathrm{it}}{ }^{\prime} \theta
$$

where I and S stand for investment (gross fixed capital formation) and saving (basic saving calculated as GDP minus private and public consumption expenditure) respectively, Y stands for GDP and CA=S-I is the current account. $\Delta$ stands for the first difference, and the subscripts $\mathrm{i}(\mathrm{i}=1,2, \ldots, \mathrm{N})$ and $\mathrm{t}(\mathrm{t}=1,2, \ldots, \mathrm{T})$ index the countries and time periods in the sample respectively. In this dynamic specification, the coefficient $\beta$ measures the short-run correlation between saving and investment, while the other parameters $\alpha, \gamma$ and $\delta$ have important long run implications for the savinginvestment relationship. In particular, $\gamma$ is the co-integrating parameter, and rejecting the hypothesis that $\gamma=0$ would imply the existence of a long-run relationship between saving and investment, with the long-run correlation between investment and saving being $(1+\delta / \gamma)$. If we cannot reject $\delta=0$, then the relationship between saving and investment is one-to-one in the long run. This is consistent with low capital mobility. It could also imply that the intertemporal budget constraint is obeyed and the current account equals some constant in the long run. If $\alpha=\delta=0$, then the current account would fluctuate around zero. On the other hand, rejecting the hypothesis $\delta=0$ would imply that the current account is non-stationary, supporting international capital mobility [see Jansen (1996)]. One cam measure the extent of international capital mobility by the estimate of $(1+\delta / \gamma)$. The variables $\mathrm{W}$ represent a set of excluded variables that in conjunction with the included explanatory variables, are sufficient to determine changes in the investment-to-GDP ratio. However, in this model, the regression parameters, as well as the vector of excluded variables $\mathrm{W}$, are not unique since they are sensitive to the parameterization adopted. To make the coefficients unique, we assume that $\mathrm{W}$ and the explanatory variables are related as follows:

$\mathrm{W}_{\mathrm{it}}=\eta_{1 \mathrm{it}}+\eta_{2 \mathrm{it}} \Delta(\mathrm{S} / \mathrm{Y})_{\mathrm{it}}+\eta_{3 \mathrm{it}}(\mathrm{CA} / \mathrm{Y})_{\mathrm{it}-1}+\eta_{4 \mathrm{it}}(\mathrm{S} / \mathrm{Y})_{\mathrm{it}-1}+\mathrm{v}_{\mathrm{it}}$

Substituting (2) into equation (1), and simplifying gives:

$\Delta(\mathrm{I} / \mathrm{Y})_{\mathrm{it}}=\alpha_{\mathrm{it}}+\beta_{\mathrm{it}} \Delta(\mathrm{S} / \mathrm{Y})_{\mathrm{it}}+\gamma_{\mathrm{it}}(\mathrm{CA})_{\mathrm{it}}+\delta_{\mathrm{it}}(\mathrm{S} / \mathrm{Y})_{\mathrm{it}-1}+\mathrm{u}_{\mathrm{it}}$

where $\alpha_{i t}=\alpha+\eta_{1 i t}^{\prime} \theta, \beta_{i t}=\beta+\eta_{2 i t}^{\prime} \theta, \gamma_{i t}=\gamma+\eta_{3 i t}^{\prime} \theta, \delta_{i t}=\delta+\eta_{4 i t}^{\prime} \theta$, and $u_{i t}=v_{i t}^{\prime} \theta$.

Note that coefficients of (3) are random while those of the Jansen model (1) are not. This is random coefficients specification used by Dar et. al (2005) for examining the short-run dynamics and the long run behaviour of the current account, and which we adapt for investigating the relationship between the complementarity between goods trade and assets trade.

The random coefficients approach not only permits an appropriate treatment of econometric endogeneity, it could also be seen as a refinement of the stochastic law relating investment rates to its main determinants [see Pratt and Schlaifer $(1984,1988)$ ]. Furthermore, the empirical results in Jansen (1998) as well as the arguments in Feldstein (1984) strongly suggest empirical approaches that pay attention to inter-country and intertemporal differences and, the random coefficients approach, as argued by AmirKhalkhali and Dar (1993), is superior to other approaches that also accommodate such differences - e.g. the random and fixed effect models. The details of estimation issues raised by a random coefficients model such as (3) can be found in Swamy (1970), Swamy and Mehta (1975), and Swamy and Tavlas $(1995,2002)$.

We consider alternative random coefficients estimators of the parameters of (3). We first estimated the model for the entire sample by pooling over all countries as well as for each country using country-specific time series data. This is to provide a basis for comparison with group-wise results, which we get by classifying the countries into 
groups according to the degree of openness in an attempt to examine the impact of trade dependence on the degree of capital mobility.

We used long term data on the seven countries to measure openness in terms of trade (exports plus imports) to GDP ratios, with greater openness being associated with higher trade-to-GDP ratios. The data permitted us to make three groups - Group I comprising the most trade dependent or open economies and Group III comprising the least open economies. The openness variable varied from 52-55\% for Group I (the UK, Canada, and Germany) to 19-22\% for Group III (the US and Japan), with the intermediate Group II (France and Italy) lying in the $42-44 \%$ range. The trade-to-GDP ratios allowed us to group the countries into three groups: Group I. Classifying countries in terms of openness in this way appears to be a better procedure than one based on an assessment of the economic policy framework within each country. A major difficulty with the latter type of classification is that trade is not entirely a matter of policy, but also of size and geography [see, for instance, Frankel and Romer (1996)]. That is, some countries trade more not necessarily because of an outward policy orientation, but because of their geographical location. Secondly, shifts in economic policies and institutions cause problems if one were to examine countries over long periods of time. To address the openness-capital mobility question, we estimated a separate ECM for each group to assess the extent to which the different groups displayed different degrees of capital mobility in the long run. If goods trade and trade in assets complement each other, we would expect that the degree of capital mobility to be relatively lower as move from Group I through to Group III.

Table 1 reports the results for the pooled sample - that is, seven countries over two decades. An examination of results shows that, at the 5 percent (or less) significance level, the GLS estimates imply a statistically significant short run as well as long run relationships between saving and investment. However, we fail to reject $\alpha=0$ and $\delta=0$, which suggests that the current account fluctuates around zero. The validity of the random coefficients model is also supported by Swamy's g-statistic that follows a $\chi^{2}$ distribution under the null hypothesis of fixed coefficients [see Swamy (1970) for more details]. To assess whether and to what extent these aggregate results mask inter-country differences, we look at the country-specific estimates of the model. These estimates are reported in Table 2.

The country-wise estimates of $\beta \square$ are positive and statistically significant for all seven countries. Note that this coefficient represents "the average contemporaneous co-movement of saving and investment in response to shocks which have hit the economy in the past" [Jansen (1996), p. 754). As reported in Table 2, these estimates of short run correlation between saving and investment vary from a low of 0.181 for France to a high of 0.943 for the US, reflecting different types of shocks hitting these economies. In the case of the co-integrating parameter $\gamma$, the countryspecific estimates are positive and statistically significant for all countries except the US. At the same time, the nonrejection of the hypotheses $\alpha=0$ and $\delta=0$ would imply that the current account fluctuates around zero for all countries except the U.S., for which the evidence does not support the presence of a co-integrating relationship between saving and investment.

Table 1

GLS Estimates Of The Random Coefficients Error-Correction Model

\begin{tabular}{|c|c|c|c|c|}
\hline Countries & $\alpha$ & $\beta$ & $\gamma$ & $\delta$ \\
\hline All & 0.2240 & $0.522^{*}$ & $0.243^{*}$ & -0.015 \\
& $(1.554)$ & $(0.166)$ & $(0.082)$ & $(0.073)$ \\
\hline \multicolumn{5}{|c|}{ g-statistic $=59.55^{*}$} \\
\hline
\end{tabular}

* indicates statistical significance at the 5\% level or less. Figures in brackets are standard errors. 
Table 2

Country-Wise GLS Estimates Of The Random Coefficients Error-Correction Model

\begin{tabular}{|c|c|c|c|c|}
\hline Countries & $\alpha$ & $\beta$ & $\gamma$ & $\delta$ \\
\hline UK & 0.2619 & $0.7247^{*}$ & $0.2472^{*}$ & 0.0048 \\
Canada & 1.0613 & $0.4264^{*}$ & $0.2305^{*}$ & -0.0675 \\
Germany & -1.4225 & $0.5052^{*}$ & $0.3379^{*}$ & 0.0265 \\
\hline France & -0.7572 & $0.1806^{*}$ & $0.3300^{*}$ & 0.0208 \\
Italy & 1.3165 & $0.2069^{*}$ & $0.1904^{*}$ & -0.0754 \\
\hline US & -0.3741 & $0.9430^{*}$ & 0.1404 & 0.0445 \\
Japan & 1.4818 & $0.6637^{*}$ & $0.2211^{*}$ & -0.0607 \\
\hline
\end{tabular}

* indicates statistical significance at the $5 \%$ level or less.

These results would suggest that the long-run relationship between investment and saving is one to one for all countries except the US. For the US, there is no support for a long-run relationship between investment and saving, whereas for the other countries, capital mobility is estimated to be low regardless of the degree of openness. Thus, these results do not point to a positive relationship between openness and capital mobility.

If openness were relevant, however, then the more appropriate estimation approach would be to apply GLS separately to Groups I, II, and III. The group-specific results are reported in Table 3 below. Looking first at the Swamy's g-statistic, we can see that the validity of the random coefficients model is supported by large value of calculated g-statistic for distinguishing between the three groups. Thus, the separate regressions are valid. At the same time, the low values of g-statistic within each group support the inclusion of those countries in the specified group. The results speak for themselves. The estimates of the short-run correlations are positive and statistically significant for all three groups, and as far as the size is concerned, the largest coefficient belongs to the least open group. However, short run correlations need not be indicators of capital mobility, since these could be due to a variety of shocks to saving and investment

Table 3

Group-Wise GLS Estimates Of The Random Coefficients Error-Correction Model

\begin{tabular}{|c|c|c|c|c|}
\hline Groups & $\alpha$ & $\beta$ & $\gamma$ & $\delta$ \\
\hline $\begin{array}{c}\text { Group I } \\
\text { UK, Canada and Germany } \\
\text { (g-statistic: 7.79) }\end{array}$ & $\begin{array}{c}2.077^{*} \\
(0.912)\end{array}$ & $\begin{array}{l}0.478^{*} \\
(0.090)\end{array}$ & $\begin{array}{c}0.264^{*} \\
(0.060)\end{array}$ & $-0.112^{*}$ \\
\hline Group II & 2.131 & & & $(0.046)$ \\
\hline $\begin{array}{l}\text { France and Italy } \\
\text { g-statistic: 3.50) }\end{array}$ & $(1.364)$ & $0.157^{*}$ & $0.202^{*}$ & -0.087 \\
\hline Group III & $1.368^{*}$ & $(0.063)$ & $(0.061)$ & $(0.067)$ \\
US and Japan & $(0.434)$ & $0.791^{*}$ & $0.183^{*}$ & $-0.054^{*}$ \\
(g-statistic: 3.36) & $(0.101)$ & $(0.047)$ & $(0.019)$ \\
\hline g-statistic: 42.46*
\end{tabular}

* indicates statistical significance at the $5 \%$ level or less. Figures in brackets are standard errors.

With regard to the co-integrating parameters, the results are again positive and statistically significant for all three groups, thereby supporting the existence of a long-run relation between saving and investment for each group of countries. At the same time, the estimation results for Group II imply that the current account fluctuates around zero since we cannot reject $\delta=0$. For the other two groups, the rejection of $\delta=0$ points to non-stationarity of the current account, and accordingly is suggestive of greater capital mobility. We find that that degree of capital mobility is greater for the most open group compared to the least open group. This can be seen by noting that the long-run correlation between investment and saving is 0.424 for the most open group, 0.569 for the intermediate group, and 0.705 for the least open group. This points to a positive, monotonic relationship between capital mobility and openness. However, we cannot be certain about the monotonicity of the relationship because with $\delta$ not being statistically significant in the intermediate group, the long run correlation of 0.569 is not statistically different from 
unity. Thus, our results lend only partial support to the hypothesis of a positive relationship between capital mobility and trade openness.

\section{CONCLUSION}

This paper examines the dynamics of saving-investment relationship in seven most industrialized countries over the last two decades using a random coefficients error correction model, to assess whether trade in goods and trade in assets are complementary. This is examined by determining whether more open economies are also economies with a greater degree of capital mobility, by estimating the correlation between saving and investment in the long run. Our estimates of the error correction model point to a statistically significant short run as well as long run relationships between saving and investment. These results also imply that the current account would fluctuate around zero in the long run. This is consistent with low long run capital mobility for this group of countries as a whole. The validity of the random coefficients model is also supported by Swamy's g-statistic. The country-wise estimates of short run correlations between saving and investment are also positive and statistically significant for all seven countries. Further, the country-specific estimates of the co-integrating parameter are positive and statistically significant for all countries except the US. At the same time, non-rejection of hypotheses $\alpha=0$ and $\delta=0$ would imply that the current account would fluctuate around zero for all countries except the U.S., for which the evidence does not support the existence of a co-integrating relationship between saving and investment.

To empirically test whether countries that are more open in terms of trade policy are also more open in terms of capital flows - that is, whether the degree of capital mobility is positively related to openness - we ranked countries by the degree of openness, which was measured by historical averages of trade-GDP ratios. The groupspecific supported the existence of a short-run as well as long run relationship between saving and investment. However, our findings do not unambiguously point to a positive monotonic relationship between capital mobility and openness. At best, there appears to be partial support to the extent that the least open group displays lower capital mobility than the most open group. We cannot categorically conclude that trade in goods and capital flows are complementary among G-7 countries. Additional testing using a larger group of countries would likely shed further light on this issue.

\section{REFERENCES}

1. AmirKhalkhali, S. and A. Dar (1993), Testing for Capital Mobility: A Random Coefficients Approach, Empirical Economics, 18, 523-541.

2. Dar, A., Sal AmirKhalkhali, and Samad AmirKhalkhali (2005), The Current Account and the Intertemporal Budget Constraint: Evidence from G-7 Countries, International Business \& Economics Research Journal, 4, 67-72.

3. Feldstein, Martin and Charles Horioka (1980) Domestic Saving and International Capital Flows, Economic Journal, February 1980, 314-29.

4. $\quad$ Feldstein, M. (1984), Tax Policy and Capital Flows, Weltwirtschaftliches Archiv, 130, 314-29.

5. Frankel, J.A. and D. Romer (1996), Trade and Growth: An Empirical Investigation, National Bureau of Economic Research (NBER) Working paper 5470, March.

6. IMF, (2002, 2003), International Financial Statistics Yearbook, Washington, D.C.

7. Jansen, W., (1996), Estimating Saving-Investment Correlations: Evidence for OECD Countries Based on an Error Correction Model, Journal of International Money and Finance, 15, 749-81.

8. Jansen, W. (1998), Interpreting Saving-Investment Correlations, Open Economies Review, 9, 205-18.

9. OECD Economic Outlook $(1999,2003)$, Organization for Economic Co-operation and Development. Paris, France.

10. Pratt, J. W. and R. Schlaifer (1984), On the Nature and Discovery of Structure, Journal of the American Statistical Association, March, 9-33.

11. Pratt, J. W. and R. Schlaifer (1988), On the Interpretation and Observation of Laws, Journal of Econometrics, September, 23-52.

12. Swamy, P.A.V.B. (1970), Efficient Inference in a Random Coefficients Regression Model, Econometrica, March, 311-23. 
13. Swamy, P.A.V.B. and J.S. Mehta (1975), Bayesian and Non-Bayesian Analysis of Switching Regressions and of Random Coefficient Regression Models, Journal of the American Statistical Association, September, 593602.

14. Swamy, P.A.V.B. and G.S. Tavlas (1995), Random Coefficient Models: Theory and Applications, Journal of Economic Surveys, 165-196.

15. Swamy, P.A.V.B. and G.S. Tavlas (2002), Random Coefficient Models, in Baltagi, B.H. (Ed.) Companion to Theoretical Econometrics, Basil Blackwell, pp. 410-428.

\section{NOTES}

